\title{
The Influence of Education and Socialization on Radicalization: An Exploration of Theoretical Presumptions and Empirical Research
}

\author{
Trees Pels • Doret J. de Ruyter
}

Published online: 24 November 2011

(C) The Author(s) 2011. This article is published with open access at Springerlink.com

\begin{abstract}
Background and Objective Research into radicalization does not pay much attention to education. This is remarkable and possibly misses an important influence on the process of radicalization. Therefore this article sets out to explore the relation between education on the one hand and the onset or prevention of radicalization on the other hand.

Method This article is a theoretical literature review. It has analyzed empirical studiesmainly from European countries - about the educational aims, content and style of Muslim parents and parents with (extreme) right-wing sympathies.

Results Research examining similarity in right-wing sympathies between parents and children yields mixed results, but studies among adolescents point to a significant concordance. Research also showed that authoritarian parenting may play a significant role. Similar research among Muslim families was not found. While raising children with distrust and an authoritarian style are prevalent, the impact on adolescents has not been investigated. The empirical literature we reviewed does not give sufficient evidence to conclude that democratic ideal in and an authoritative style of education are conducive to the development of a democratic attitude.

Conclusion There is a knowledge gap with regard to the influence of education on the onset or the prevention of radicalization. Schools and families are underappreciated sources of informal social control and social capital and therefore the gap should be closed. If there is a better understanding of the effect of education, policy as well as interventions can be developed to assist parents and teachers in preventing radicalization.
\end{abstract}

Keywords Radicalization · Content of education - Style of education · Socialization

T. Pels $(\varangle) \cdot$ D. J. de Ruyter

Faculty of Psychology and Education, VU University Amsterdam, Van der Boechorststraat 1,

1081BT Amsterdam, The Netherland

e-mail: t.v.m.pels@vu.nl 


\section{Introduction}

In the Netherlands, the debate about immigration and integration has hardened over the years, even more so than in other European countries. Much of the debate focuses on Muslim minorities, who are perceived as a single group despite their highly diverse ethnic background. The building of mosques, the use of religious symbols such as the headscarf, gender inequality, anti-integration pronouncements by ultra-orthodox imams, and Islaminspired political extremism are all popular subjects in the media (e.g. Uitermark et al. 2005). In addition to a change in views about Islam in the Western world, an impetus for the negative climate was the brutal murder of film director and media personality Theo van Gogh by Mohammed B., son of Moroccan migrants in November 2004 (see Buruma 2006). During the first months after the murder, radicalized youngsters made the headlines of the (internet) press on an almost daily basis. Since then, attention to Muslim terrorism has steadily declined. This does not mean, however, that the threat of radicalization amongst Muslim youngsters has diminished or that the soil for terrorism has become less fertile, for a negative attitude against Islam is still highly prevalent.

The openly Islamophobic Freedom Party of Geert Wilders had a landslide victory in the 2010 elections, becoming the third largest party. A trend study about polarization and radicalization in 2009 also concludes that there is a growing number of interethnic confrontations and an increase in tensions and confrontations with an Islamophobic nature. Indigenous youngsters tend to think more negatively about their immigrant peers than vice versa. This is not only true for extreme right youths, but also for the 'average' Dutch youngsters (Moors et al. 2009). Although the majority of citizens believe that polarization is a bigger problem than radicalization, they do relate the increase in opposing positions to immigrants, Muslims especially (Moors et al. 2009). It is clear that in this environment the relation of Muslim youngsters to the Dutch society is under pressure (e.g. Pels 2003); what is more, these developments can contribute to an increased attachment of youngsters to Islam. A research of Entzinger and Dourleijn (2008) in Rotterdam for instance shows that amongst Moroccan youngsters, scoring lowest on the ethnic hierarchy in the Netherlands (Hagendoorn 2007) and feeling more often rejected than other migrant groups (Moors et al. 2009), the number of practicing Muslims increases. A growing number is willing to participate in legal activities like demonstrations to show their aggravation. Many youngsters experience a 'wall of distrust', which for some of them means that they no longer take an interest in their environment and its rules and eventually live up to the negative expectations that others have against them (see also Harris 1995).

The upraise of the populist parties with right-wing populist political messages may not only be a risk for the radicalization of Muslim youngsters, but may also infuse right-wing extremism, because right-wing convictions are openly preached. The fact that right-wing views are no longer politically incorrect may be a stepping stone to extremist views. Although the future may also show that the increasing political power of people with these convictions reduces the likelihood that they will become extremists, the current Dutch society seems to face a looming danger on two sides. Moreover, it is well possible that the growth of right-wing extremism and Islamic radicalism reinforce each other.

Thus, we suggest that research into prevention of radicalization is still imperative, but more importantly, we want to argue that it requires an additional focus, namely on the socialization and educational environments within which children and youngsters develop. While there is a growing research interest into the socio-psychological antecedents of radicalization (e.g. Moghaddam 2005; Van den Bos et al. 2009), there is not much insight into the relation between socialization, education and radicalization. Available facts, 
however, provide us with sufficient indications that this knowledge gap needs to be closed. Radicalization is more prevalent amongst adolescents and young adults (15-30 years) and trends show that youngsters radicalize at a younger age (Buijs et al. 2006; Sageman 2008; Slootman and Tillie 2006). ${ }^{1}$ Moreover, the developmental tasks of adolescents-among which are developing a personal, social and political identity, redefining bonds and relations and forming new relationships-make them vulnerable to radical beliefs. This is particularly the case when for instance (perceived) exclusion and personal or group threat, being uprooted and/or an experienced gap with the adult world lie at the root of this vulnerability (Buijs et al. 2006; Moghaddam 2005). A vigilant attitude by institutions responsible for children's socialization and education, especially families and schools, toward nascent radicalization seems to be in place (e.g. Hagan et al. 1995).

After a brief elucidation of the terms radicalization and extremism, we describe our theoretical presumptions with regard to the relation between two central aspects of parenting and school education on the one hand and radicalization on the other hand. Next, we present insights from an analysis of existing empirical research, for which we mainly draw from three European countries in which upbringing in Muslim families and by parents with right-wing sympathies have been investigated most extensively. However, although the research is drawn from these countries, our claim that research about radicalization needs to include the education and socialization of youngsters, is not specific to those countries. Moreover, we suggest that researchers in all Western societies should investigate important educational influences on phenomena of polarization and radicalization, also in order to enable the development of preventive measures. For this reason, this article addresses an international audience. In addition to a call for further research, our article ends with the suggestion that assistance to parents and schools that diminishes the development of radicalization has to be developed.

\section{Radicalism and Extremism}

'Radical' does not necessarily have a negative meaning. As the dictionary teaches us, the first, and non-pejorative meaning of being radical is 'Arising from or going to a root or to the basis'. An example of a radical person, in this sense of the word, is someone who wants to change the domination and pollution of the consumer market and advocates that all consumer products of multi-nationals be banned and that only local produce should be sold. This is, however, not the dominant meaning, which is 'departing markedly from the existing or being extreme'. Although close to our example, this meaning has a negative connotation, which is related to the phrase 'being extreme'. In this definition, the difference between radicalism and extremism seems to evaporate. This has actually happened in our common language. Both concepts are being used for the same type of conviction and disposition, at least for radicalism in the negative sense-and this has become the dominant conception of radicalism (Mandel in press).

However, although the terms are used for the same type of convictions and dispositions, they tend to refer to different groups. While academic literature on extremism in recent years also covers radicalized Muslims, 'extremism' tends to represent political and particularly right-wing political viewpoints. 'Radicalism' on the other hand almost exclusively

\footnotetext{
1 Sageman (2008), for instance, shows that in consecutive waves of terrorism, the age of Islamic terrorists has declined since the $80 \mathrm{~s}$, from an average of thirty to early twenty. It is, however, not only prevalent in adolescence; older persons are involved in (planned) attacks too.
} 
stands for the views of Islamist fundamentalists who use illegal and/or immoral means to spread their beliefs or found their utopian state (see for instance Schmid and Price 2011). It should also be noted that in current academic and popular literature the difference between radicalism and terrorism has become a very thin line. Much literature on radicalization deals with terrorism (see Schmid and Price 2011). We do not equate radicalization with terrorism. While some radicalized persons and right wing extremists may not shy away from terrorist acts, others may use less extreme ways to impose their views on other people. We follow Mandel (in press) who proposes as a working definition of radicalization: 'an increase in and/or reinforcing of extremism in the thinking, sentiments, and/or behavior of individuals and/or groups of individuals' (p. 20).

Research into right-wing and Muslim radicalism seems to indicate that there are similar socialization and developmental patterns. For instance, in both cases feelings of unjust treatment and of insecurity and perceived fraternal deprivation can lead to the development of radical beliefs and acts (Reinares et al. 2008; Van den Bos et al. 2009). The Netherlands can function as an example to illustrate this point.

We already noted in the introduction that the debate in the Netherlands about Islam and Muslims has become quite extreme. Proposals by Wilders' Party for Freedom to put a tax on the wearing of scarves (which he malignly calls the head rag tax) or Wilders' reference to Muslim voters as 'voting cattle' are telling examples. In such a hostile environment we may expect a rise in feelings of relative deprivation, ${ }^{2}$ (perceived) injustice and group threat (e.g. Moghaddam 2005; Silke 2008; Van den Bos et al. 2009), which can lead to feelings of uncertainty (e.g. Hogg 2004; Moghaddam 2005). This, in turn can motivate people to finding other securities, and the clear rules and distinct groups of radicalized peers are then attractive alternatives. Various empirical studies indeed show that there is a relation between real and perceived deprivation, feelings of powerlessness and low self-esteem on the one hand and radicalization on the other hand (Buijs et al. 2006; Kuhn 2004).

Young Muslims in the Netherlands have a high risk to experience these threats to their 'self'. In addition to their (perceived) exclusion for being a migrant or Muslim adverse living conditions may also take their toll. The majority grows up in ethnically diverse neighborhoods in which there is an accumulation of problems: poverty, school failure, health and behavioral problems, unemployment, disruptive behavior and criminality (e.g. Pels et al. 2009). These circumstances also influence parental upbringing, because parents have fewer social sources available. Moreover, possibilities for collective socialization in the neighborhood are being challenged (for instance Leventhal and Brooks-Gunn 2000). For native youngsters who feel or are deprived of opportunities, the strong and relatively simple right-wing message that particular groups are to blame, may be highly appealing. In the Netherlands, native youth in rural areas clash with immigrant youth out of frustration about (perceived) negative interethnic relations, interethnic competition and the loss of their 'imagined community' due to the rapid influx of migrants during the past decennia (Cadat and Engbersen 2006; Van der Valk and Wagenaar 2010).

Researchers, however, also agree that radicals, extremists, and terrorists have different backgrounds and that there is not a specific or special factor that all persons share in their personality or history (see for instance Silke 2008), although some do suggest that there are

\footnotetext{
${ }^{2}$ Relative deprivation is a form of (perceived) discrimination resulting from social comparison. This could be a realistic or real type of discrimination for instance in politics or economic circumstances, and a symbolic type of discrimination through stigmatization or negative stereotyping (Riek, Mania, \& Gaertner, 2006). The last type is also called interactional and procedural (in)justice, i.e. perceived deprivation in interpersonal interaction and institutional approach. (Perceived) deprivation is possible at both an individual and a collective level.
} 
general phases or steps in the process of radicalization (Bandura 2004; Moghaddam 2005; Porter and Kebbell 2011). When researchers investigate determinants (see for an overview Silke 2008), they tend to look at characteristics of the individual (biological, psychological), at environment or context, and at interactions between these two. Reinares et al. (2008), for instance, state that the commonality between all forms of radicalization leading towards violence is

that it always takes place at the intersection of an enabling environment and a personal trajectory. Not all individuals who share the same sense of injustice or are living in the same polarized environment turn to radicalism and even less to violence and terrorism. Concrete personal experiences, kinship and friendship, group dynamics and socialization into the use of violence are needed to trigger the actual process. (p. 9).

We want to add that parents and teachers are well placed to influence children and youngsters, both towards radicalization as well as to the prevention of this process.

\section{Theoretical Premises About the Influence of Education}

Empirical research has indicated that the level of education of radicalized youngsters and adults does not have a strong influence on (prevention) of radicalization (see for instance Silke 2008). Among radicalized persons, one can find well-educated persons as well as those without a diploma. It may therefore not come as a surprise that in the U.S. for instance, where radicalization and particularly terrorism receive a lot of scientific and political attention, education is hardly included in an attempt to counter radicalization (see Webber 2011). However, the education youngsters receive from their parents and in schools includes much more than academic level.

We believe that it is important to pay attention to two aspects of education in families and schools, namely the content of the education youngsters receive as well as the style with which parents and teachers raise and educate children and youngsters. For both aspects, we formulate a positive and negative premise.

1. The content (aims and ideals) of the upbringing and education of parents and teachers

(a) It is theoretically plausible to presume that parents and teachers who have radicalized or extremist convictions aim to transmit these ideals and values to the children they are responsible for. For, if one is convinced of the (moral or religious) truth of one's ideals and values, one will want to ensure that children will also be as strongly convinced. All fundamentalist, radicalized and extremist educators share the propensity to indoctrinate. Whether or not they are successful is obviously a different matter. However, we may assume that children will be influenced by the ideal-driven education they receive and that there is a likelihood that children come to adopt these ideals.

(b) In contrast, it is reasonable to assume that youngsters will adopt democratic ideals if they are fostered by educators. Since Dewey (1903), many educationalists have suggested that the development of children into democratic citizens is furthered if they are raised in democratic schools. If parents and teachers aim to educate children towards democratic citizens who have respect for the rights of others and to tolerate beliefs, religious or otherwise, that are different from their own (see for instance Davies 2009; Webber 2011), the education that children 
and youngsters receive cultivates beliefs and dispositions that oppose radicalism and extremism.

More particularly, we may assume on theoretical grounds that moral education can prevent radicalization. Extremists perform activities that they possibly had never thought they would be capable of. Bandura (2002, 2004) suggests that moral disengagement might play an important role in this process. Under the umbrella of disengagement, he describes several mechanisms, such as redefining harmful conduct by moral justification, euphemistic labeling of acts, minimizing or misconstruing the consequences, dehumanization of the other or attribution of blame on the victim. Democratic moral education may have an important role in adequately responding to signs of moral distancing.

2. The style of parenting or teaching

(a) The authoritarian style of education is characterized by demanding strict obedience and by a lack of explanation or justification of the rules children and youngsters are expected to follow (see Baumrind 1966). Such a style will not contribute to the development of critical thinking and negotiation and therefore does not diminish the chance of radicalization. Equally, lack of openness to discuss views does not further the openness to others.

(b) It seems reasonable to assume that there is a positive relation between an authoritative educational style and democratic attitude of children-which may have a preventive influence on the development of radicalization. If parents are open to a discussion with their children, if they give their reasons for their beliefs and decisions and if they allow children to negotiate (which does not mean that children have a say in everything), they further a democratic attitude in their children. For instance, authoritative Muslim parents may be able to enhance the development of what is called 'polder Islam': a type of faith that corresponds with the discussion and coalition culture in the Netherlands (Buitelaar 2009). Equally, we suggest that there are good reasons to presume that inclusive approaches in multi-ethnic schools, like creating a sense of community through cooperative learning and developing democratic and justice-oriented communities (e.g. Hansen 2001; Westheimer and Kahne 2004), instead of accentuating assimilation and control, has a diminishing effect on the onset of radicalization. Of course, the style of education in itself is not sufficient but should be complemented with an appropriate content. It is, for instance, possible that parents with an authoritative parenting style have racist ideals or believe that their ethnic or religious identity is being threatened, which they also pass onto their children. It is therefore important to make a clear distinction between educational aims or ideals on the one hand and the style of education on the other hand.

\section{Methods}

We have analyzed theoretical and empirical studies about upbringing in Muslim families and the content and style of education of parents with (extreme) right-wing sympathies in relation to radicalization of their adolescent children. As mentioned, there is hardly any 
research about this relationship (see for instance Schmid and Price 2011), particularly in the case of Muslim youngsters, and therefore we also use more general empirical research about these youngsters and those with latent right-wing sympathies to see if they are socialized in an environment that makes them more or less prone to radicalize. Empirical studies about Muslim families were mainly drawn from the Netherlands where a lot of empirical research has been conducted with regard to the socialization and educational situation of Muslim youngsters. Thus, insights from research within the Dutch context, which has specific challenges for both categories of youngsters, will be used as prime examples of existent knowledge. Empirical research into the socialization history of youth with right-wing sympathies is scarce in the Netherlands. Therefore, our main sources of information about this group will be from other countries, Germany and Belgium in particular.

\section{Results}

Families and Parental Education

Research of Zenter and Renaud (2007) that specifically looked at the similarity of ideals within families shows that the similarity is mainly due to the culture of the environment in which the family lives. After correcting for cultural factors, the similarity between the ideal selves of parents and children is low, due to what they call a telephone game effect.

... the message [ideals of the parents, inserted by authors] is altered because not everything that parents wish for themselves do they also wish for their children. Subsequently, the message is altered again because the latter perceive what parents wish for their children with imperfect accuracy. A final transmutation of the message occurs because parental ideals, even if accurately perceived, are not always accepted by the child. (p. 569)

However, this is possibly different for the two groups we are interested in. Parents with right-wing extremist sympathies and Muslim parents may have a stronger wish to pass on their ideals and values to their children, particularly because their views differ from those of the mainstream culture. Indeed, research of Boehnke et al. (2007) showed that the distance of the family from what they call Zeitgeist affects intra-familial value similarity. It can also be suggested that if the family culture differs from the mainstream culture, which is the case in the majority of Muslim migrant families and of right wing native families, intergenerational similarity of ideals and values can be attributed to the influence of parents. Vedder et al. (2008) for instance found that in immigrant groups the ethnic Zeitgeist played a significant role in adolescents' acceptance of family obligations.

Empirical research that particularly focuses on the influence of parental ideals and aims on the onset of radicalization of Muslim youngsters is, however, not prevalent. A source that might be helpful is that on ethnic socialization. Anglo-Saxon literature mentions different strategies of ethnic (or racial) socialization in the family (e.g. Hughes et al. 2006), with two poles that can concisely be described as follows: parents can use more open or 'dual' parenting strategies, in which ethno-cultural loyalty coincides with openness towards the 'other' (e.g. Lafromboise et al. 1993), or more defensive or antagonistic coping styles that may inculcate an attitude of distrust in their children and may make them more prone to conflict vis-à-vis the 'other'. The latter may possibly influence the onset of radicalization. Qualitative research on parenting in Dutch minority families points to more or less defensive or antagonistic attitudes vis-à-vis society at large. Particularly Muslim 
parents of the first generation transfer a certain distrust towards their environment (Pels et al. 2009), but there is insufficient knowledge about the influence of this distrust on youngsters. Nor do we know how parents respond to children who are under the influence of radical Islamists, or how radicalization influences family relations.

In contrast, there is empirical research about the similarity of right-wing convictions between parents and children. Research examining similarity in xenophobia between parents and pre-adolescent children yields mixed results, but studies among adolescents point to a significant concordance (Gniewosz and Noack 2006). Duriez, Soenens and Vansteenkiste (2007) discovered that parental goals do predict Right-Wing Authoritarianism and Social Dominance Orientation and Duriez and Soenens' research (2009) corroborated the conclusion of a few studies among adolescents that there is a significant concordance in racism between parents and their adolescent children, which in their study was found to result largely "from a more fundamental intergenerational transmission of ideology" (p. 906). German studies examining anti-foreigner and national-authoritarian attitudes also found similarities between parents and their adolescent children (Kracke et al. 1993; Noack and Kracke 2000), indicating processes of role modeling in the area of right wing extremism. Whether or not this is true for migrant families whose culture also differs from the mainstream culture is an important empirical question.

There is also empirical research available about the influence of parenting styles and rightwing extremism in youngsters. Higher scores of adolescents on xenophobia, as one indicator of right-wing extremism, were found in families characterized by lower emotional relatedness (Kracke et al. 1993). A more punitive and authoritarian-rigid parenting style has been associated with more right-wing attitudes (Fend 1991), more xenophobia (Hefler et al. 1999), and stronger authoritarian characteristics (Rebenstorf et al. 2000) in adolescents. Altogether, we conclude that, besides the direct influences of parents as role-models, parental style as indicated by poor emotional relationships and communication and by authoritarian parenting may play a significant role in the socialization of deviant political behavior.

There is no similar empirical research available with regard to the relation between radicalization amongst Muslim youngsters and the parenting style of parents. However, empirical research does show that the parenting style of Muslim parents may not have an inhibiting effect on radicalization. Muslim parents in the Netherlands rank conformity and moral obeisance higher and autonomy lower as parental goals compared to native Dutch parents, though much of this difference diminishes when educational level is taken into account (Pels and De Haan 2007; Pels et al. 2006). Qualitative data, however, point to differences in meaning attached to the same goals. The Muslim parents interpret autonomy in a less individualistic sense and conformity in a less egalitarian sense than Dutch parents. The differences regarding parental goals are reflected in parents' educational style. Authoritative control is fairly common within Dutch families, whereas restrictive control is more salient within minority families, who use both types of controlling techniques to about the same extent. Maintaining authority and communication with their children in a culture of egalitarian social interaction is perceived by them as a more difficult task (Pels et al. 2006).

Youngsters in these circles also perceive a lack of open communication with their parents (e.g. Pels 2003; Pels et al. 2008). This lack of openness may have various consequences. Firstly, it has been shown that in general children risk being marginalized when they are raised in a 'cold family' in which there are also conflicts about authority (e.g. Patterson and Yoerger 2002; Pels 2003; Stevens et al. 2007). Young Muslims tend to receive less parental support than indigenous Dutch youngsters do. Particularly their fathers tend to be much less involved (Pels et al. 2006). Research amongst Moroccan families shows that this is particularly true for boys: they cannot turn to their parents as 
easily as girls, which means that they are more dependent on their peers (De Jong 2007; Pels and De Haan 2007; Stevens et al. 2004). Girls are educated in a stricter way; for them Islam can be a way to strive for autonomy and freedom (Pels et al. 2009).

\section{Schools and Schooling}

Schools are in principle a good place for youngsters from different ethnic backgrounds to bridge the ethnic boundaries. Schools are one of the contexts where peers meet, informally but also in task-oriented settings. Schools may bring pupils together who may have not otherwise developed relationships. Furthermore, these groups can provide the social skills that may enhance other relationships (O'Koon 1997). Research, however, indicates that we should not be too optimistic in our expectations. Interethnic contacts in schools do not significantly increase (Bakker et al. 2007). Moreover, youngsters tend to withdraw into their own ethnic groups outside the school context (Interculturele verhoudingen op Amsterdamse scholen, 2005). In general, research on the 'contact-hypothesis' (increased interethnic contact leads to a decrease of prejudice and an increase of interaction across ethnic borders) shows that this hypothesis is not corroborated on a wide scale. Contact leads to positive interactions only in specific contexts, for instance if groups are equal in their position on the status hierarchy (Lindo 2008).

We have not found empirical research that focuses on the similarity between radical ideals and values of teachers and pupils. Empirical research into the influence of democratic ideals and moral values of teachers and schools on pupils and thereby the decrease of radicalization is similarly hard to find. There is some evidence that teachers' interventions with xenophobic utterances of pupils are negatively related to xenophobia of pupils (Bacher 2001). In other words, intervening matters. However, not all teachers seem to have great interest in the socialization of their pupils in this sense. As Pels (2011) concludes on the basis of a review of Dutch literature, a crystallized view on dealing with diversity on a religious, cultural or ethnic basis, or with tensions on these issues is still farfetched. Research of the city of Amsterdam (Gemeente Amsterdam 2005) among 25 schools for secondary education points to an increase in incidents between groups of pupils as well as between minority pupils and teachers. Teachers interviewed by Leeman (2003) report problems with teaching on politically laden subjects as the Middle East, terrorist attacks or religion.

Not only the content of education is of importance, but also teaching competence and style. Leeman (2003) found that teachers are at a loss finding ways to handle difficult discussions in which respect and consensus are difficult to reach. In order to ensure that lessons can continue orderly and to maintain a relatively peaceful atmosphere in the class, teachers tend to avoid topics that touch on religious and ethnic-cultural diversity. Apart from the fact that teachers may lack competencies to effectively cope with tensions in the classroom, they may apply a more or less authoritarian style of approaching their pupils. As we argued, their educational style can also have a positive or negative influence on radicalization, just as we discussed for parents. Interestingly, schools that provide vocational education-where minority pupils are overrepresented-tend to prefer authoritarian education instead of interactive or participative education (Mooren 2006; Onstenk 2006). Again, this does not seem to be an effective style for developing democratic dispositions and acting.

Research in Amsterdam (Gemeente Amsterdam 2005) shows that generally the commitment or loyalty of minority children to their school is greater if there is more individual attention for students. This last finding is corroborated in other research: young Muslims mention the important support they felt from a single teacher who did take notice and interest (Pels 2008; Pels et al. 2009). This is an important fact, because youngsters who are 
susceptible to radicalization tend to have a strong need for acknowledgement and relationships (Buijs et al. 2006). The literature, however, also mentions more or less conscious exclusion of pupils by teachers. Observation research shows that some teachers discern 'we' from 'you' 'us from 'them' when addressing migrant pupils or their communities of descent (Duits 2008). Ascribing representations and identities to students, or discounting their deviating views as 'exceptions' is not uncommon (Koole and Hanson 2002). The negative influence of discrimination and different treatment of children from minority groups on their well-being at school or college, motivation and achievements is broadly documented (e.g. De Graaf et al. 2006; Dilworth and Brown 2001; Severiens et al. 2008; Wubbels et al. 2006).

Since (perceived) deprivation is one of the major root causes for radicalization, we may conclude that current practices in schooling often do not seem apt to diminish the susceptibility to radicalization in youngsters. Citizenship education might be one of the answers. In response to threats to democracy by a violent political Islam and extremism from the right, and the resulting social instability and feelings of insecurity, many western countries have welcomed citizenship to their political and educational agenda (Brubaker 2001). However, in many Dutch schools citizenship education is taking a one-sided turn, accentuating individual rights and (moral) obligations and focusing on students of nonwestern descent to assimilate. It does not stimulate teachers and students to take a reflective stance on inequalities and cultural pluralism in society (Leeman and Pels 2006).

Finally, it may not only be the education within families or schools in itself that has an influence on the onset of radicalization, it is also possible that a lack of a good functioning (inter ethnic) civil society is an obstacle. We may presume that interaction and preferably co-operation between families and schools will have a diminishing effect on radicalization. Particularly for youngsters who are vulnerable due to perceived discrimination and injustice in society and who are searching for an authority figure, the cooperation between these socializing institutions might be crucial. Recently, there is a growing interest in collective socialization, which is an active engagement between and cooperation of informal and formal educators in the community. Examples are a communal formulation of rules (intergenerational closure), exchange of information and advice and informal social control and support. These forms of social capital are not self-evident, on the contrary, one of the undermining factors is the presence of an ethnic heterogeneous population-and concomitant language, social and cultural hurdles (Sampson et al. 1999).

Available Dutch research shows that the two educational domains we have highlighted are often separate islands that are unable to realize sufficient bridging. In practice cooperation between parents and schools often plods along heavily (Pels 2011). On the contrary, both parties may even hinder or undermine each other's intentions. For example, research in Amsterdam schools showed that parents and schools differed in the messages they provided about the murder of Theo van Gogh (Visser and Slot 2005) and another study among Amsterdam schools showed that a wider gap between migrant parents and the school increases the distance between migrant and native youngsters (Interculturele verhoudingen 2005). This could lead to an educational vacuum of which the signs are visible in the public domain in which groups of youngsters take a lead in their own socialization (Pels 2003).

\section{In conclusion}

Research on radicalization tends to focus on adolescents, because it is likely that radicalization finds its roots in this developmental stage. There is a growing research interest 
into the socio-psychological antecedents of radicalization. An interesting use of general psychological insights into the reduction of extremist views can be found in Lilienfeld et al. (2009), who plea for extending research into debiasing interventions. They translate the results of the psychological research on biases in general into proposals for debiasing adults and children who have radicalized views. These include psychoeducational methods to combat 'confirmation bias' pivotal to ideological extremism and inter- and intra-group conflict. Education about specific cognitive biases, perspective taking, active open-mindedness and delayed decision making are among the methods that might be of use.

Research into parental upbringing and education in schools is far from complete. We stated that it is plausible to assume a relation between the ideals of education on the one hand and the onset or prevention of radicalization on the other hand. The intergenerational transmission of ideology, so we argued, may be profound in the context of migration, inducing more intensified communication about ethnic-cultural or religious differences. There is empirical research that showed a relation between extreme right-wing convictions of parents and those of their children. It is important that this research be expanded and also includes Muslim families, for ideological transmission has not been researched within these families. In addition, we claimed to have good reasons for believing that the style of education has a positive or negative influence on the onset of radicalization. More particularly, we presupposed that an authoritative style of education is conducive to the development of a democratic attitude-provided it is complemented with the appropriate democratic content. The empirical literature we reviewed does not give us sufficient evidence to be able to conclude that this presumption is correct.

We also formulated the presumption that democratic ideals and moral education can prevent radicalization, by adequately responding to signs of moral distancing and stimulating adherence to moral rules and respect for the liberal moral rights of others. The available literature again does not offer much information on these issues. However, we did find that minority and native parents as well as and teachers struggle with their educational tasks in the multi-ethnic context, especially with respect to the tensions, conflicts and discrimination that may arise in this context.

We believe it is of eminent importance that the knowledge gap in this field be closed. Firstly, particular attention should be given to the way in which parents pass on ideas and evaluations about society, which difficulties parents experience when their youngsters come under the influence of radical peers or organizations, which influence this has on family life and how parents can be assisted. Secondly, it is important to investigate the aims and content (and ideals) of education that parents and teachers provide as well as the influence of these aims and content on the development of a democratic disposition or radicalization of youngsters. If we have a better understanding of these two issues, policy can be developed to assist parents and teachers in educating youngsters, with a particular view to prevent radicalization.

Thus, this knowledge is not only important for scientists, but may be helpful for developing interventions that support parents and teachers (Weine et al. 2009). Schools and families are underappreciated sources of informal social control and social capital that may constrain Islamic radicalism and right-wing extremism. We believe that it is important that not only specific programs are developed, but that general programs for parental support and family interventions also enclose scientific knowledge about the specific difficulties parents can face in a multi-ethnic context. Moreover, in current teacher education and social work training-programs, little attention is given to the fact that a significant number of families come from other regions of the world, or face the challenge to raise their children in a multi-ethnic context (e.g. Pels 2010). Parents and pupils can be more 
successfully supported if social workers and teachers are sensitive to their needs, committed to giving them a voice and competent to deal with controversial issues (Davies 2009; Howard and Hodes 2000; Pels 2011). Such improvements are highly important, but not sufficient we should add. We do agree with De Winter (2006), who suggests that it is unlikely that changing education of youngsters who are radicalizing is efficient if governments do not take sufficient effort to change society into a truly democratic and just one. Youngsters should experience that it is indeed in their favour to act and think democratically. If there is no advantage for them, they might lose faith in democracy. Thus, the state should not only stimulate democratic education, but also be a model to the youngsters and aim to ensure that all citizens are able to make use of their democratic rights and fulfil their democratic duties.

Acknowledgments We thank the editor and anonymous reviewers for their stimulating comments about the first version of the article.

Open Access This article is distributed under the terms of the Creative Commons Attribution Noncommercial License which permits any noncommercial use, distribution, and reproduction in any medium, provided the original author(s) and source are credited.

\section{References}

Bacher, J. (2001). In welchen Lebensbereichen lernen Jugendliche Ausländerfeindlichkeit? Kölner Zeitschrift für Soziologie und Sozialpsychologie, 53(2), 334-349.

Bakker, J., Denessen, J., Pelzer, B., Veneman, M., \& Lageweg, S. (2007). De houding jegens klasgenoten: etnisch gekleurd? Een onderzoek naar factoren van invloed op de attitude van basisschoolleerlingen jegens klasgenoten van verschillende etnische herkomst. Pedagogiek, 27(3), 201-222.

Bandura, A. (2002). Selective moral disengagement. Journal of Moral Education, 31(2), 101-120.

Bandura, A. (2004). The role of selective moral disengagement in terrorism and counterterrorism. In F. M. Moghaddam \& A. J. Marsella (Eds.), Understanding Terrorism: psychosocial roots, consequences, and interventions (pp. 121-150). Washington: American Psychological Association.

Baumrind, D. (1966). Effects of authoritative parental control on child behavior. Child Development, 37(4), 887-907.

Boehnke, K., Hadjar, A., \& Baier, D. (2007). Parent-child value similarity. The role of Zeitgeist. Journal of Marriage and Family, 69(3), 778-792.

Brubaker, R. (2001). The return of assimilation? Changing perspectives on immigration and its sequels in France, Germany, and the United States. Ethnic and Racial Studies, 24(4), 531-548.

Buijs, F. J., Demant, F., \& Hamdy, A. (2006). Strijders van eigen bodem. Radicale en democratische moslims in Nederland. Amsterdam: Amsterdam University Press.

Buitelaar, M. (2009). Van huis uit Marokkaans. Levensverhalen van hoogopgeleide migrantendochters. Amsterdam: Bulaaq.

Buruma, I. (2006). Murder in Amsterdam. The death of Theo van Gogh and the Limits of Tolerance. New York: Penguin Press.

Cadat, M., \& Engbersen, R. (2006). Lonsdale-clash op het verstedelijkte platteland. Tijdschrift voor Sociale Vraagstukken, 3, 8-14.

Davies, L. (2009). Educating against extremism: towards a critical politicisation of young people. International Review of Education, 55(2-3), 183-203.

De Graaf, D., De Jong, U., \& Van der Veen, I. (2006). Staken of switchen binnen het hbo: kunnen instellingen hun studenten behouden? Tijdschrift voor Hoger Onderwijs, 24(4), 218-228.

De Jong, J. D. (2007). Kapot moeilijk. Een etnografisch onderzoek naar opvallend delinquent groepsgedrag van Marokkaanse jongens. Amsterdam: Aksant.

De Winter, M. (2006). Democratie-opvoeding versus de code van de straat. In R. Janssens, T. Schillemans, \& M. de Winter (Eds.), Opvoeding tot democratie (pp. 11-32). Amsterdam: SWP.

Dewey, J. (1903). Democracy in Education. In J. A. Boydston (Ed.), (1980) John Dewey. The middle works. Vol. 3, 1903-1906 (pp. 229-239). Carbondale and Edwardsville: Southern Illinois University Press. 
Duits, L. (2008). Multi-girl culture: An ethnography of doing identity. Amsterdam: Amsterdam University Press.

Duriez, B., \& Soenens, B. (2009). The intergenerational transmission of racism: the role of right-wing authoritarianism and social dominance orientation. Journal of Research in Personality, 43(5), 906-909.

Duriez, B., Soenens, B., \& Vansteenkiste, M. (2007). In search of the antecedents of adolescent authoritarianism: The relative contribution of parental goal promotion and parenting style dimensions. European Journal of Personality, 21, 507-727.

Entzinger, H., \& Dourleijn, E. (2008). De lat steeds hoger: de leefwereld van jongeren in een multi-etnische stad. Assen: Van Gorcum.

Fend, H. (1991). Identitätsentwicklung in der Adoleszenz. Lebensentwürfe, Selbstfindung und Weltaneignung in beruflichen, familiären und politisch-weltanschaulichen Bereichen. Entwicklungspsychologie der Adoleszenz in der Moderne (Band 2). Bern/Stuttgart: Huber.

Gemeente Amsterdam. (2005). Interculturele verhoudingen op Amsterdamse scholen voor voortgezet onderwijs en middelbaar beroepsonderwijs. Amsterdam: Gemeente Amsterdam.

Gniewosz, B., \& Noack, P. (2006). IntergenerationaleTransmissions- und Projektionsprozesse intoleranter. Einstellungen zu Ausländer in der Familie. Zeitschrift für Entwicklungspsychologie und Pädagogische Psychologie, 38(1), 33-42.

Hagendoorn, L. (2007). The relation between cultures and groups. Valedictory lecture. Utrecht: Oratiereeks Universiteit Utrecht.

Hansen, D. T. (2001). Teaching as a moral activity. In V. Richardson (Ed.), Handbook of research on teaching (4th ed., pp. 826-857). Washington: AERA.

Harris, J. R. (1995). Where is the child's environment? A group socialization theory of development. Psychological Review, 102(3), 458-489.

Hefler, G., Boehnke, K., \& Butz, P. (1999). Zur Bedeutung der Familie für die Genese von Fremdenfeindlichkeit bei Jugendlichen: Eine Längsschnittanalyse. Zeitschrift für Soziologie der Erziehung und Sozialisation, 19(1), 72-87.

Hogg, M. A. (2004). Uncertainty and extremism: Identification with high entitativity groups under conditions of uncertainty. In V. Yzerbyt, C. M. Judd, \& O. Corneille (Eds.), The psychology of group perception: Perceived variability, entitativity, and essentialism (pp. 401-418). New York: Psychology Press.

Howard, M., \& Hodes, M. (2000). Psychopathology, adversity, and service utilization of young refugees. Journal of the American Academy of Child and Adolescent Psychiatry, 39(3), 368-377.

Hughes, D., Smith, E. P., Stevenson, H. C., Rodriguez, J., Johnson, D. J., \& Spicer, P. (2006). Parents' ethnic-racial socialization practices: A review of research and directions for future study. Developmental Psychology, 42(5), 747-770.

Interculturele verhoudingen op Amsterdamse scholen voor voortgezet onderwijs en middelbaar beroepsonderwijs (2005). n.p.

Koole, T., \& Hanson, M. (2002). The category 'Moroccan' in a multi-ethnic class. In S. Hester \& W. Housley (Eds.), Language, interaction and national identity: Studies in the social organisation of national identity in talk-in-interaction (pp. 211-232). Burlington: Ashgate.

Kracke, B., Noack, P., Hofer, M., \& Klein-Allermann, E. (1993). Die rechte Gesinnung: Familiale Bedingungen autoritärer Orientierung ost- und westdeutscher Jugendlicher. Zeitschrift für Pädagogik, 39(5), 971-988.

Kuhn, H. P. (2004). Adolescent voting for right-wing extremist parties and readiness to use violence in political action: parent and peer contexts. Journal of Adolescence, 27(5), 561-582.

Lafromboise, T., Coleman, H. L. K., \& Gerton, J. (1993). Psychological impact of biculturalism: Evidence and theory. Psychological Bulletin, 114(3), 395-412.

Leeman, Y. (2003). De pedagogische opdracht in een multi-etnische context: docentendilemma's. Pedagogische Studien, 80(6), 468-484.

Leeman, Y., \& Pels, T. (2006). Citizenship Education in the Dutch Multi-Ethnic Context. European Education, 38(2), 64-76.

Leventhal, T., \& Brooks-Gunn, J. (2000). The neighbourhoods they live in: the effects of neighbourhood residence on child and adolescent outcomes. Psychological Bulletin, 126(2), 309-337.

Lindo, F. (2008). Interetnische contacten tussen scholieren in het voortgezet onderwijs: Een analyse en waardering van het onderzoek binnen het paradigma van de contacthypothese. Amsterdam: IMES.

Mandel, D. R. (in press). Radicalization: What does it mean? In T. Pick, \& A. Speckhard (Eds.), Indigenous terrorism: Understanding and addressing the root causes of radicalization among groups with an immigrant heritage in Europe Amsterdam: IOS Press. 
Moghaddam, F. M. (2005). The staircase to terrorism. A psychological exploration. American Psychologist, $60(2), 161-169$.

Mooren, F. (2006). Opvoeding op school en in het gezin: Onderzoek naar de samenhang tussen opvoeding en de houding van jongeren ten opzichte van sociale grenzen. Groningen: RUG (dissertatie).

Moors, H., Balogh, L., Van Donselaar, J., \& De Graaff, B. (2009). Polarisatie en radicalisering in Nederland: Een verkenning van de stand van zaken in 2009. Tilburg: IVA.

Noack, P., \& Kracke, B. (2000). Haltungen Jugendlicher gegenüber Ausländern und Ausland: Verschiedene Aspekte und differentielle Einflüsse In H. P. Kuhn, H. Uhlendorff \& L. Krappmann (Eds.), Sozialisation zur Mitbürgerlichkeit (pp. 171-193). Opladen: Leske+Budrich.

O'Koon, J. (1997). Attachment to Parents and Peers in Late Adolescence and Their Relationship with SelfImage. Journal of Adolescence, 32(4), 470-482.

Onstenk, J. (2006). Moet het onderwijs opvoeden of de ouders? Vernieuwing, 65(8), 6-8.

Patterson, G. R., \& Yoerger, K. (2002). A developmental model for early- and late-onset antisocial behavior. In J. B. Reid, J. Snyder, \& G. R. Patterson (Eds.), Antisocial behavior in children and adolescents: A developmental analysis and model for intervention (pp. 147-172). Washington, DC: American Psychological Association.

Pels, T. (2003). The question of respect: Socialization and misconduct of Moroccan boys in the Netherlands. The Netherlands' Journal of Social Sciences, 39(2), 126-142.

Pels, T. (2008). The tension between learning and socializing with peers: disengagement and pedagogical context in two multi-ethnic junior classes in the Netherlands. In M. Hajer \& T Koole (Eds.), Interaction in two multicultural mathematics classrooms Mechanisms of inclusion and exclusion (pp. 197-235). Amsterdam: Aksant.

Pels, T. (2010). Opvoeden in de multi-etnische stad (oratie). Utrecht/Amsterdam: Verwey-Jonker Instituut/ Vrije Universiteit.

Pels, T. (2011). De pedagogische functie van het onderwijs. Utrecht: Verwey-Jonker Instituut.

Pels, T., \& De Haan, M. (2007). Socialization practices of Moroccan families after migration: a reconstruction in an 'acculturative arena'. Young. Nordic Journal of Youth Research, 15(1), 71-91.

Pels, T., Distelbrink, M., \& Postma, L. (2009). Opvoeding in de migratiecontext. Review van recent onderzoek naar de opvoeding in gezinnen van nieuwe Nederlanders, in opdracht van NWO. Utrecht: Verwey-Jonker Instituut.

Pels, T., de Gruijter, M., \& Lahri, F. (2008). Jongeren en hun islam. Jongeren over hun ondersteuning als moslim in Nederland. Utrecht: Verwey-Jonker Instituut/FORUM.

Pels, T., Nijsten, C., Oosterwegel, A., \& Vollebergh, W. (2006). Myths and realities of diversity in child rearing. Minority families and indigenous Dutch families compared. In M. Deković, T. Pels, \& $\mathrm{S}$. Model (Eds.), Child rearing in six ethnic families: The multi-cultural dutch experience (pp. 213-245). Lewiston: Edwin Mellen Press.

Porter, L. E., \& Kebbell, M. R. (2011). Radicalization in Australia: Examining Australia's convicted terrorists. Psychiatry Psychology and Law, 18(2), 212-231.

Rebenstorf H, Schmid C, Kuhn HP (2000) Autoritäre Reaktion und Erziehungsstil Zur Entwicklung autonomer Persönlichkeit. In: HP Kuhn, H Uhlendorff, L Krappmann (Eds.), Sozialisation zur Mitbürgerlichkeit. (pp. 37-57), Leske+Budrich, Opladen.

Reinares, F., Alonso, R., Björgo, T., Della Porta, D., Coolsaet, R., Khosrokhavar, F., De Vries, G. (2008). Radicalization processes leading to acts of terrorism: A concise report prepared by the European Commission's expert group on violent radicalization. N.p.

Riek, B. M., Mania, E. W., \& Gaertner, S. L. (2006). Intergroup threat and outgroup attitudes. A metaanalytic review. Personality and Social Psychology Review, 10(4), 336-353.

Sageman, M. (2008). Leaderless Jihad. Terror Networks in the Twenty-first century. Philadelphia: Penn Press.

Schmid, A. P., \& Price, E. (2011). Selected literature on radicalization and de-radicalization of terrorists: Monographs, edited volumes, grey literature and prime articles published since the 1960s. Crime, Law and Social Change, 55, 337-348.

Severiens, S., Wolff, R., Meeuwisse, M., Rezai, S., \& De Vos, W. (2008). Waarom stoppen zoveel allochtone studenten met de Pabo? Samenvatting van vijf studies. SBO: Den Haag.

Silke, A. (2008). Holy warriors: Exploring the psychological processes of Jihadi radicalization. European Journal of Criminology, 5(1), 99-123.

Slootman, M., \& Tillie, J. (2006). Processen van radicaliserin. Waarom sommige Amsterdamse moslims radicaal worden. Amsterdam: IMES.

Stevens, G., Pels, T., Vollebergh, W., \& Crijnen, A. (2004). Patterns of psychological acculturation in adult and adolescent Moroccan immigrants living in The Netherlands. Journal of Cross-Cultural Psychology, 35(6), 689-704. 
Stevens, G., Vollebergh, W., Pels, T., \& Crijnen, A. (2007). Problem behavior and acculturation in Moroccan immigrant adolescents in the Netherlands: Effects of gender and parent-child conflict. Journal of Cross-Cultural Psychology, 38(3), 310-317.

Uitermark, J., Rossi, U., \& Van Houtum, H. (2005). Reinventing multiculturalism: urban citizenship and the negotiation of ethnic diversity in Amsterdam. International Journal Urban and Regional Research, 29(3), 622-640.

Van den Bos, K., Loseman, A., \& Doosje, B. (2009). Waarom jongeren radicaliseren en sympathie krijgen voor terrorisme: onrechtvaardigheid, onzekerheid en bedreigde groepen. Den Haag: WODC/Ministry of Justice.

Van der Valk, I., \& Wagenaar, W. (2010). Monitor racisme \& extremisme. In en uit extreemrechts. Amsterdam: Amsterdam University Press.

Vedder, P., Berry, J., Sabatier, C., \& Sam, D. (2008). The intergenerational transmission of values in national and immigrant families: The role of Zeitgeist. Journal of Youth and Adolescence, 38(5), $642-653$.

Webber, D. (2011). Education as counterterrorism tool and the curious case of the Texas school book resolution. Available at: http://works.bepress.com/diane_webber/10. Accessed 11 June 2011.

Weine, S., Horgan, J., Robertson, Ch., Loue, S., Mohamed, A., \& Noor, S. (2009). Community and family approaches to combating the radicalization and recruitment of Somali-American youth and young adults: A psychosocial perspective. Dynamics of Asymmetric Conflict, 2(3), 181-200.

Westheimer, J., \& Kahne, J. (2004). What kind of citizen? The politics of educating for democracy. American Educational Research Journal, 41(2), 237-269.

Wubbels, T., Den Brok, P., Veldman, I., \& Van Tartwijk, J. (2006). Teacher interpersonal competence for Dutch secondary multicultural classrooms. Teachers and teaching: Theory and practice, 12(4), 407-433.

Zenter, M., \& Renaud, O. (2007). Origins of adolescents' ideal self: An integrated perspective. Journal of Personality and Social Psychology, 92(3), 557-574. 